Попко О. В., к.е.н., доцент (Національний університет водного господарства та природокористування, м. Рівне)

\title{
ВІТЧИЗНЯНИЙ ЗАКОНОДАВЧИЙ БАЗИС АДАПТАЦІї ДО ЄВРОПЕЙСЬКОЇ МОДЕЛІ КОНТРОЛЮ ЯКОСТІ ТА БЕЗПЕЧНОСТІ ХАРЧОВОї ПРОДУКЦІї
}

Обґрунтовано доцільність та пріоритетні напрямки запровадження міжнародної системи контролю якості та безпечності харчової продукції вітчизняними операторами ринку. Проведено аналіз законодавчої бази України з питань якості та безпечності харчової продукції. Окреслено переваги від запровадження в практику вітчизняних промислових підприємств базових принципів системи XАССП.

Ключові слова: продовольча безпека, експортна стратегія, оператори ринку, державне регулювання безпечності продукції, система ХАССП.

Гарантування продовольчої безпеки є пріоритетним напрямком розвитку аграрного сектору України, ключовими стратегічними цілями якого являються забезпечення населення країни якісним, безпечним, доступним продовольством, а також розширення участі України на світовому ринку продукції сільського господарства та продовольства.

Основи наукових досліджень механізмів забезпечення продовольчої безпеки закладені в працях видатних зарубіжних і вітчизняних економістів, серед яких: К. Голікова, М. Гребенюк, А. Гатаулін, А. Діброва, С. Кваша, Т. Лозинська, Л. Мармуль, О. Могильний, М. Одінцова, І. Румик, А. Ульянченко, О. Шевченко, В. Щербань, В. Шкабкрін та ін. Питання розвитку підгалузей харчової промисловості України на різних етапах досліджували такі вітчизняні вчені, як П. Борщевський, Л. Дейнеко, А. Заїнчковський, Н. Карпенко, Є. Крикавський, П. Купчак, Д. Крисанов, М. Мальчик, М. Окландер, П. Осіпов, Л. Пашнюк, В. Пилипчук, В. Прядко, М. Сичевський, Н. Скопенко, Л. Чернюк та ін.

Проте ряд теоретичних, методичних і практичних аспектів проблеми розвитку аграрного сектору економіки України в частині процесів адаптації до європейських вимог щодо якості й безпечності сільськогосподарської сировини та харчових продуктів, залишається 
вкрай актуальними. Відповідно постає питання формування дієвого механізму забезпечення продовольчої безпеки України шляхом переходу вітчизняної системи безпечності і якості харчової продукції на міжнародні стандарти, запровадження передових систем якості й безпечності продукції вітчизняними операторами ринку, адаптації вітчизняної харчової продукції до вимог зовнішніх ринків збуту.

У світовій практиці питаннями забезпечення продовольчої безпеки на глобальному рівні займається Продовольча і сільськогосподарська організація ООН (ФАО), яка функціонує з квітня 1945 р. Основи досягнення продовольчої безпеки на міжнародному рівні, на рівні країни, регіону, окремо взятого домогосподарства чи індивіда було схвалено Римською декларацією про всесвітню продовольчу безпеку і Планом дій, прийнятими на Всесвітній продовольчій конференції в 1996 р. у Римі. В подальшому Концепція міжнародної продовольчої безпеки знайшла своє відображення в ряді політичних документів «Великої сімки» [18]. У вересні 2015 р. на 70-й ювілейній сесії Генеральної Асамблеї ООН було схвалено Програму глобального світового розвитку до 2030 р., яка визначає базові принципи щодо реалізації Концепції міжнародної продовольчої безпеки.

На сьогодні в Україні, яка є одним із стратегічних партнерів ФАО, після схвалення Програми глобального світового розвитку до 2030 р., виникла нагальна необхідність внесення змін до програми «ФАО-Україна» $з$ фокусуванням на питаннях адаптації вітчизняної продукції до міжнародних стандартів якості й безпечності та активізації участі України в забезпеченні міжнародної продовольчої безпеки. Разом з тим, у грудні 2017 р. Уряд затвердив Експортну стратегію України [2] на період 2017-2021 рр., яка визначає стратегічні цілі розвитку торгівлі України на наступні чотири роки, серед яких: створення умов для розвитку сфер торгівлі задля диверсифікації експорту українських товарів та послуг, підтримка експорту з боку держави, а також підвищення рівня знань та навичок, необхідних підприємствам для здійснення міжнародної торгівлі. До перспективних секторів економіки України віднесено також харчову і переробну промисловість [2].

Однією з ключових складових дотримання Концепції міжнародної продовольчої безпеки та Експортної стратегії України є забезпечення високого рівня якості харчової продукції. В Україні з цією метою напрацьована певна законодавча база - це Закони: «Про безпечність та якість харчових продуктів» [4], «Про внесення змін до деяких законодавчих актів України щодо харчових продуктів» [6], «Про вилучення з обігу, переробку, утилізацію, знищення або подальше 
використання неякісної та небезпечної продукції» [5], «Про державний контроль за дотриманням законодавства про харчові продукти, корми, побічні продукти тваринного походження, здоров'я та благополуччя тварин» [7], «Про державне регулювання імпорту сільськогосподарської продукції» [8], «Про державну систему біобезпеки при створенні, випробуванні, транспортуванні та використанні генетично модифікованих організмів» [9], «Про забезпечення санітарного та епідемічного благополуччя населення» [11], «Про захист прав споживачів» [12], «Про основні принципи та вимоги до безпечності та якості харчових продуктів» [13], «Про Перелік документів дозвільного характеру у сфері господарської діяльності» [14], «Про стандартизацію» [15] та ін.

Новий підхід до державного регулювання безпечності харчової продукції передбачає використання терміну «оператор ринку харчових продуктів» (далі - оператор ринку) замість термінів «фізична або юридична особа» та «оператор потужностей». У трактуванні ЗУ «Про основні принципи та вимоги до безпечності та якості харчових продуктів» [13] оператором ринку може бути як фізична, так і юридична особа, яка здійснює діяльність з метою або без мети отримання прибутку (наприклад, розповсюдження харчових продуктів на благочинних ярмарках з метою рекламування та пригощання потенційних покупців). Оператором ринку також вважається агропромисловий ринок. При цьому вітчизняні оператори ринку зобов'язані: 1) нести відповідальність за виконання вимог законодавства про безпечність та окремі показники якості харчових продуктів у межах діяльності, яку вони здійснюють; 2) дотримуватись харчового законодавства на всіх стадіях виробництва та обігу («від лану до столу»). До обов'язків оператора ринку належить і отримання експлуатаційного дозволу документу дозвільного характеру, який видається компетентним органом на підставі результатів перевірки відповідності його потужностей вимогам санітарних заходів та дає змогу оператору ринку провадити господарську діяльність з виробництва та/або зберігання харчових продуктів тваринного походження.

Відтак при виході на ринки ЄС вітчизняні експортери повинні в обов'язковому порядку дотримуватись основних принципів і вимог базового законодавства $€ С$ з безпечності харчових продуктів та кормів, а також з державного контролю у сфері санітарних та фітосанітарних заходів (рисунок). 


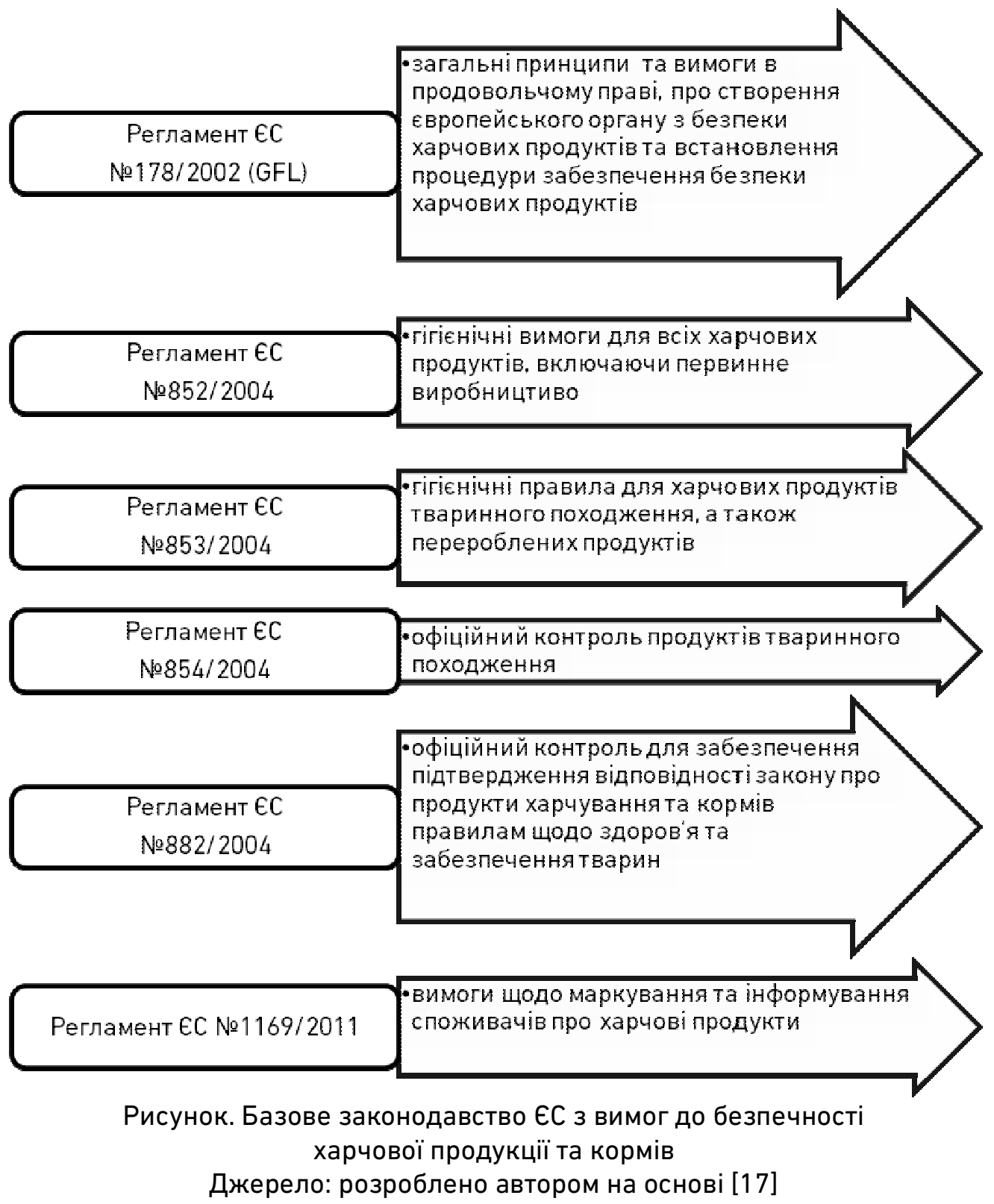

Згідно Всеохоплюючої стратегії імплементації Глави IV (Санітарні та фітосанітарні заходи) Розділу IV «Торгівля і питання, пов'язані $з$ торгівлею» Угоди про асоціацію між Україною, $з$ однієї сторони, та Європейським Союзом, Європейським Співтовариством 3 атомної енергії і їхніми державами-членами, з іншої сторони [17], було встановлено план заходів та строки їх впровадження на території України. Так, у 2016 р. було впроваджено базові принципи і вимоги безпечності харчових продуктів та кормів згідно Регламентів ЄС № 178/2002, № 852/2004, № 854/2004; у 2018 р. - заходи, пов'язані 3 
державним контролем у сфері санітарних та фітосанітарних заходів згідно Регламентів ЄС № 853/2004, № 882/2004, № 854/2004, а також заходи, які застосовуються щодо маркування згідно Регламенту ЄС № 1169/2011 та ін. Недотримання вимог законодавства про безпечність та неналежне забезпечення показників якості харчових продуктів щодо гігієнічних вимог до харчових продуктів на всіх стадіях їх виробництва та обігу, тягне за за собою накладання штрафу на юридичних осіб - у розмірі від двох до восьми мінімальних заробітних плат; на фізичних осіб - підприємців - у розмірі від двох до п'яти мінімальних заробітних плат. Виробництво, зберігання харчових продуктів без отримання експлуатаційного дозволу тягне за собою накладення штрафу на юридичних осіб - у розмірі від тридцяти до тридцяти восьми мінімальних заробітних плат, на фізичних осіб - підприємців - у розмірі від двадцяти трьох до тридцяти мінімальних заробітних плат [4].

3 метою дотримання вимог законодавства про безпечність та якість харчових продуктів на всіх стадіях їхнього виробництва та обігу оператори ринку зобов'язані запровадити на своїх підприємствах постійно діючі процедури, засновані на принципах системи НАССР/ ХАССП (далі - система ХАССП) [10]. Система ХАССП являє собою систему аналізу ризиків, небезпечних чинників і контролю критичних точок, що дозволяє гарантувати виробництво безпечної продукції, назва якої $€$ абревіатурою від заголовних букв англомовних слів Hazard Analysis and Critical Control Points, що в перекладі означає «Аналіз ризиків і контролю критичних точок» [20]. Система ХАССП $є$ ключовим нормативним документом, який містить вимоги до принципів управління безпечністю харчових продуктів для будь-яких операторів, які бажають працювати в рамках законодавства у сфері харчової безпеки на провідних міжнародних ринках. Система ХАССП забезпечує більш структурований підхід до контролю ідентифікованих небезпек біологічного, хімічного чи фізичного походження. Використання системи ХАССП дає змогу перейти від контролю якості готової продукції на стадії завершення виробничого циклу до запровадження превентивних методів упродовж усього виробничого ланцюга. Відповідно до ХАССП харчовий ланцюг («food chain») являє собою послідовність стадій та операцій, що включають виготовлення, оброблення, дистрибуцію, зберігання й перероблення засобів для харчування і харчових продуктів, від первинного виробництва до споживання. Тобто, виробничий ланцюг розглядається як єдиний процес, протягом якого повинні бути усунуті всі чинники, що можуть призвести до виробництва недоброякісної та небезпечної для здо- 
ров'я людини продукції [10]. На основі принципів ХАССП у багатьох країнах світу розроблено відповідні національні стандарти, що містять вимоги до систем безпеки харчових продуктів.

В країнах Європейського союзу, США та Канаді впровадження систем ХАССП є обов'язковим для всіх підприємств харчової промисловості. На основі принципів ХАССП у багатьох країнах світу розроблено відповідні національні стандарти, що містять вимоги до систем безпеки харчових продуктів. ХАССП $є$ основою для таких міжнародних стандартів якості та безпечності харчової продукції, як BRC британський стандарт асоціації роздрібних торговців, IFS - міжнародний стандарт харчових продуктів, Dutch ХАССП - голландський стандарт системи ХАСCП, FSSC 22000:2010 - стандарт для виробників окремих категорій харчових продуктів, об'єднуючий вимоги ISO 22000:2005 та PAS 220:2008, прийнятий об'єднанням Глобальної ініціативи з безпечності харчових продуктів (GFSI). В даний час більшість торговельних мереж та крупних харчових компаній, зокрема: McDonald's Corporation, The Coca-Cola Company, Wal-Mart Stores Inc., Kraft Foods Inc., METRO Group, Danone пред'являють до своїх постачальників вимоги щодо наявності сертифіката відповідності системи менеджменту одному з визнаних GFSI стандартам і системам сертифікації.

З 2005 р. на основі базових принципів ХАССП Міжнародною організацією по стандартизації (ISO) було прийнято міжнародний стандарт ISO 22000:2005 «Системи управління безпечністю харчових продуктів. Вимоги до будь-яких організацій харчового ланцюга». 3 1 січня 2006 р. система ХАССП стала обов'язковою до запровадження країнами ЄС. Стандарт ISO 22000:2005 поєднує принципи аналізу ризиків у контрольних критичних точках і практичні рекомендації, представлені в Кодексі Аліментаріус щодо гігієни продуктів харчування. Вимоги Міжнародного стандарту ISO $22000 €$ прийнятними для всіх типів організацій у харчовій сфері.

32011 р. ХАССП стає основою міжнародного стандарту з якості й безпечності харчових продуктів FSSC 22000. У вітчизняній практиці управління якістю й безпечністю харчової продукції з 1 липня 2003 р. було введено в дію стандарт ДСТУ 4161-2003 «Системи управління безпечністю харчових продуктів. Вимоги», з 1 серпня 2007 р. вступив в дію національний стандарт ДСТУ ISO 22000:2007 «Системи управління безпечністю харчових продуктів. Вимоги до будь-яких організацій харчового ланцюга». 3 жовтня 2012 р. згідно Наказу Міністерства аграрної політики та продовольства України № 590 було затверджено Вимоги щодо розробки, впровадження та застосування постійно діючих процедур, заснованих на принципах Системи управлін- 
ня безпечністю харчових продуктів (НАССР) [10]. 31 липня 2013 р. згідно Наказу Міністерства економічного розвитку № 1356 від 28.11.2012 р. було введено ДСТУ-H CAC/RCP 1:2012 «Продукти харчові. Настанови щодо загальних принципів гігієни» (CAC/RCP 1-1969, Rev. 4-2003). У червні 2014 р. Верховна Рада України проголосувала за Проект Закону про внесення змін до деяких законодавчих актів України щодо харчових продуктів №4179а, який стосується гармонізації законодавства країни та Європейського Союзу у сфері безпеки та якості харчових продуктів.

Висновки. У цілому вдосконалення законодавства України в сфері продовольчої безпеки, його наближення до законодавства $Є С$ та вимог СОТ має стати стимулом для розвитку міжнародної торгівлі, активізації участі України в забезпеченні міжнародної продовольчої безпеки. Водночас наближення вітчизняних стандартів до міжнародних потребуватиме багато зусиль від влади та додаткових фінансових витрат. Важливими елементами наближення законодавства до міжнародних стандартів $€$ зміцнення довіри через створення/ведення належної практики нормативного регулювання та контролю якості харчових продуктів. Активніше звернення за порадами до регуляторних органів ЄС, обмін досвідом та інформацією, сприятимуть формуванню достатнього рівня довіри до України з боку $€ C$ та інших країн-партнерів й тіснішої кооперації [21]. Водночас кінцеві споживачі отримають доступ до безпечної для споживання продукції високої якості, що, своєю чергою, підвищить довіру до харчової продукції та товаровиробників, які їх виготовляють. Таким чином, завдяки процесам переходу харчового законодавства України до міжнародних стандартів, відбуватиметься усунення торговельних бар'єрів для виходу українських компаній на міжнародні ринки у відношенні визнання країнами-імпортерами еквівалентності вітчизняних стандартів якості та безпечності харчової продукції, що своєю чергою сприятиме диверсифікації експортних ринків України, а відтак - активізації участі України в забезпеченні міжнародної продовольчої безпеки.

1. Господарський кодекс України від 16.01.2003 р. № 436-IV. Законодавство України. Відомості BP України. URL: http:// http://zakon.rada.gov.ua/laws/show/436-15. (дата звернення: 15.01.2019). 2. Експортна стратегія України. URL: https://www.ukrinform.ua/rubriceconomy/2410968-eksportna-strategia-ukraini-mert-pocav-drugij-etaprozrobki.html. (дата звернення: 15.01.2019). 3. Кодекс України про адміністративні правопорушення від 07.12.1984 р. № 51. Законодавство України. ВР України. URL: http:// http://zakon.rada.gov.ua/laws/show/80731-10/ed19841207. (дата звернення: 15.01 .2019$)$. 4. Про безпечність та якість харчових продуктів : 
Серія «Економічні науки»

Випуск 3(83) 2018 р.

Закон України від 28.12.2014 р. № 67-VIII. URL:

http://zakon4.rada.gov.ua/laws/show/1602-18. (дата звернення: 15.01.2019).

5. Про вилучення з обігу, переробку, утилізацію, знищення або подальше використання неякісної та небезпечної продукції : Закон України від 14.01.2000р. № 1393-XIV. URL: http://zakon.rada.gov.ua/laws/show/1393-14. (дата звернення: 15.01.2019). 6. Про внесення змін до деяких законодавчих актів України щодо харчових продуктів : Закон України від 22.07.2014 р. № 1602-VII. URL: http://zakon.rada.gov.ua/laws/show/1602-18. (дата звернення: 15.01.2019). 7. Про державний контроль за дотриманням законодавства про харчові продукти, корми, побічні продукти тваринного походження, здоров'я та благополуччя тварин : Закон України від 18.05.2017 р. № 2042-VIII. URL: http://zakon.rada.gov.ua/laws/show/2042-19. (дата звернення: 15.01.2019). 8. Про державне регулювання імпорту сільськогосподарської продукції : Закон України від 09.07 .2003 р. № 1046-IV. URL: http://zakon.rada.gov.ua/laws/show/1046-15. (дата звернення: 15.01.2019). 9. Про державну систему біобезпеки при створенні, випробуванні, транспортуванні та використанні генетично модифікованих організмів : Закон України від 23.02.2012 р. № 4441-VI. URL: http://zakon.rada.gov.ua/laws/show/4441-17. (дата звернення: 15.01.2019). 10. Про затвердження Вимог щодо розробки, впровадження та застосування постійно діючих процедур, заснованих на принципах Системи управління безпечністю харчових продуктів (НАССР) : Наказ Міністерства аграрної політики та продовольства від 01.10.2012 р. № 590. URL: http://zakon2.rada.gov.ua/laws/show/z1704-12. (дата звернення: 15.01.2019). (дата звернення: 15.01.2019). 11. Про забезпечення санітарного та епідемічного благополуччя населення : Закон України від 24.02.1994 р. № 4004-XII. URL: http://zakon.rada.gov.ua/laws/show/4004-12. (дата звернення: 15.01.2019). 12. Про захист прав споживачів : Закон України від 12 травня 1991 р. № 1023-XII. URL: http://zakon.rada.gov.ua/laws/main/1023-12. (дата звернення: 15.01.2019). 13. Про основні принципи та вимоги до безпечності та якості харчових продуктів : Закон України від 23.12.1997 р. № 771/97-ВР. URL: http://zakon.rada.gov.ua/laws/main/771/97-\%D0\%B2\%D1\%80. (дата звернення: 15.01.2019). 14. Про Перелік документів дозвільного характеру у сфері господарської діяльності : Закон України від 18.12.2011 р. № 47. URL: http://zakon.rada.gov.ua/laws/show/3392-17. (дата звернення: 15.01.2019). 15. Про стандартизацію : Закон України від 05.06.2014 р. № 1315-VII. URL: http://zakon.rada.gov.ua/laws/show/1315-18. (дата звернення: 15.01.2019). 16. Угода про асоціацію між Україною, з однієї сторони, та Європейським Союзом, Європейським співтовариством з атомної енергії і їхніми державамичленами, 3 іншої сторони від 16.09.2014 p. URL: http:// http://zakon.rada.gov.ua/laws/show/984_011. (дата звернення: 15.01.2019). 17. Про схвалення Всеохоплюючої стратегії імплементації Глави IV (Санітарні та фітосанітарні заходи) Розділу IV «Торгівля і питання, пов'язані з торгівлею» Угоди про асоціацію між Україною, з однієї сторони, та Європейським Союзом, Європейським Співтовариством з атомної енергії і їхніми державами-членами, 3 іншої сторони : Розпорядження КМУ від 24.02.2016 р. № 228-p. URL: https://zakon.rada.gov.ua/laws/show/228-2016-\%D1\%80 (дата звернення: 
15.01.2019). 18. Совместное заявление по всемирной продовольственной безопасности. Аквильская инициатива по продовольственной безопасности (АИПБ). Документ принят главами государств и правительств «Группы восьми» 08-10.07. 2009 г. : пер. с англ. URL: http://archive.kremlin.ru/ events/articles/2009/07/219334/219445.shtml/. (дата звернення: 15.01.2019). 19. Codex Alimentarius Internationsl Food Standart. URL: http:// http://www.fao.org/fao-who-codexalimentarius/home/en/. (дата звернення: 15.01.2019). 20. HACCP. Questions \& Answers / International HACCP Alliance. URL: http://www.haccpalliance.org/sub/qanda.html. (дата звернення: 15.01.2019). 21. JohansonLennart (2006). Trade Facilitation through Equivalenceand Mutual Recognition - Lessonslearnt: URL: http://www.cclac.org/seminarios/Equivalencia/ljohanson/06-1030\%20 Johanson\%20Equivalence\%20and\%20MRA.doc. (дата звернення: 15.01.2019).

\section{REFERENCES:}

1. Hospodarskyi kodeks Ukrainy vid 16.01 .2003 r. № 436-IV. Zakonodavstvo Ukrainy. Vidomosti VR Ukrainy. URL: http:// http://zakon.rada.gov.ua/laws/show/436-15. (data zvernennia: 15.01.2019). 2. Eksportna stratehiia Ukrainy. URL: https://www.ukrinform.ua/rubriceconomy/2410968-eksportna-strategia-ukraini-mert-pocav-drugij-etaprozrobki.html. (data zvernennia: 15.01.2019). 3. Kodeks Ukrainy pro administra-tyvni pravoporushennia vid 07.12.1984 r. № 51. Zakonodavstvo Ukrainy. VR Ukra-yiny. URL: http:// http://zakon.rada.gov.ua/laws/show/80731-10/ed19841207. (data zvernennia: 15.01.2019). 4. Pro bezpechnist ta yakist kharchovykh produktiv : Zakon Ukrainy vid 28.12.2014 r. № 67-VIII. URL: http://zakon4.rada.gov.ua/laws/show/1602-18. (data zvernennia: 15.01.2019). 5. Pro vyluchennia $z$ obihu, pererobku, utylizatsiiu, znyshchennia abo podalshe vykorystannia neiakisnoi ta nebezpechnoi produktsii : Zakon Ukrainy vid 14.01.2000 r. № 1393-XIV. URL: http://zakon.rada.gov.ua/laws/show/139314. (data zvernennia: 15.01.2019). 6. Pro vnesennia zmin do deiakykh zakonodavchykh aktiv Ukrainy shchodo kharchovykh produktiv : Zakon Ukrainy vid 22.07.2014 r. № 1602-VII. URL: http://zakon.rada.gov.ua/laws/show/160218. (data zvernennia: 15.01.2019). 7. Pro derzhavnyi kontrol za dotrymanniam zakonodavstva pro kharchovi produkty, kormy, pobichni produkty tvarynnoho pokhodzhennia, zdorovia ta blahopoluchchia tvaryn : Zakon Ukrainy vid 18.05.2017 r. № 2042-VIII. URL: http://zakon.rada.gov.ua/laws/show/204219. (data zvernennia: 15.01.2019). 8. Pro derzhavne rehuliuvannia importu silskohospodarskoi produktsii : Zakon Ukrainy vid 09.07.2003 r. № 1046-IV. URL: http://zakon.rada.gov.ua/laws/show/1046-15. (data zvernennia: 15.01.2019). 9. Pro derzhavnu systemu biobezpeky pry stvorenni, 
vyprobuvanni, transportu-vanni ta vykorystanni henetychno modyfikovanykh orhanizmiv : Zakon Ukrainy vid 23.02.2012 r. № 4441-VI. URL: http://zakon.rada.gov.ua/laws/show/4441-17. (data zvernennia: 15.01.2019). 10. Pro zatverdzhennia Vymoh shchodo rozrobky, vprovadzhennia ta zastosuvannia postiino diiuchykh protsedur, zasnovanykh na pryntsypakh Systemy upravlinnia bezpechnistiu kharchovykh produktiv (NASSR) : Nakaz Ministerstva ahrarnoi polityky ta prodovolstva vid 01.10.2012 r. № 590. URL: http://zakon2.rada.gov.ua/laws/show/z1704-12. (data zvernennia: 15.01.2019). (data zvernennia: 15.01.2019). 11. Pro zabezpechennia sanitarnoho ta epidemichnoho blahopoluchchia naselennia : Zakon Ukrainy vid 24.02.1994 r. № 4004-XII. URL: http://zakon.rada.gov.ua/laws/show/4004-12. (data zvernennia: 15.01.2019). 12. Pro zakhyst prav spozhyvachiv : Zakon Ukrainy vid 12 travnia 1991 r. № 1023-XII. URL: http://zakon.rada.gov.ua/laws/main/1023-12. (data zvernennia: 15.01.2019). 13. Pro osnovni pryntsypy ta vymohy do bezpechnosti ta yakosti kharchovykh produktiv : Zakon Ukrainy vid 23.12.1997 r. № 771/97-VR. URL: http://zakon.rada.gov.ua/laws/main/771/97-\%D0\%B2\%D1\%80. (data zvernennia: 15.01.2019). 14. Pro Perelik dokumentiv dozvilnoho kharakteru u sferi hospodarskoi diialnosti : Zakon Ukrainy vid 18.12.2011 r. № 47. URL: http://zakon.rada.gov.ua/laws/show/3392-17. (data zvernennia: 15.01.2019). 15. Pro standartyzatsiiu : Zakon Ukrainy vid 05.06.2014 r. № 1315-VII. URL: http://zakon.rada.gov.ua/laws/show/1315-18. (data zvernennia: 15.01.2019). 16. Uhoda pro asotsiatsiiu mizh Ukrainoiu, z odniiei storony, ta Yevropeiskym Soiuzom, Yevropeiskym spivtovarystvom z atomnoi enerhii i yikhnimy derzhavamy-chlenamy, $z$ inshoi storony vid 16.09.2014 r. URL: http:// http://zakon.rada.gov.ua/laws/show/984_011. (data zvernennia: 15.01.2019). 17. Pro skhvalennia Vseokhopliuiuchoi stratehii implementatsii Hlavy IV (Sanitarni ta fitosanitarni zakhody) Rozdilu IV «Torhivlia i pytannia, poviazani z torhivleiu» Uhody pro asotsiatsiiu mizh Ukrainoiu, z odniiei storony, ta Yevropeiskym Soiuzom, Yevropeiskym Spivtovarystvom z atomnoi enerhii i yikhnimy derzhavamy-chlenamy, z inshoi storony : Rozporiadzhennia KMU vid 24.02.2016 r. № 228-r. URL: https://zakon.rada.gov.ua/laws/show/228-2016\%D1\%80 (data zvernennia: 15.01.2019). 18. Sovmestnoe zaiavlenie po vsemirnoi prodovolstvennoi bezopasnosti. Akvilskaia initsiativa po prodovolstvennoi bezopasnosti (AIPB). Dokument pryniat hlavami hosudarstv i pravitelstv «Hruppy vosmi» 08-10.07. 2009 h. : per. s anhl. URL: http://archive.kremlin.ru/ events/articles/2009/07/219334/219445.shtml/. (data zvernennia: 15.01.2019). 19. Codex Alimentarius Internationsl Food Standart. URL: http:// http://www.fao.org/fao-whocodexalimentarius/home/en/. (data zvernennia: 15.01.2019). 20. HACCP. Questions \& Answers / International HACCP Alliance. URL: http://www.haccpalliance.org/sub/qanda.html. (data zvernennia: 15.01.2019). 21. JohansonLennart (2006). Trade Facilitation through Equiva-lenceand Mutual Recognition - Lessonslearnt: URL: 
http://www.cclac.org/seminarios/Equivalencia/ljohanson/06-10-

30\%20 Johanson\%20Equivalence\%20and\%20MRA.doc. (data zvernennia:

15.01.2019).

Рецензент: д.е.н., професор Мальчик М. В. (НУВГП)

Popko 0. V., Candidate of Engineering (Ph.D.), Associate Professor

(National University of Water and Environmental Engineering, Rivne)

\section{NATIONAL LEGISLATIVE BASIS OF ADAPTATION TO THE EUROPEAN MODEL FOR QUALITY CONTROL AND FOOD SAFETY}

Food security is a priority direction for the development of agrarian sector of Ukraine, where key strategic goals are to provide the population with quality, safe and affordable food, as well as to increase Ukraine's participation in the world market of agricultural products and food. Nowadays, Ukraine is one of the strategic partners of FAO and needs to make changes in the FAO-Ukraine program with a focusing on the adaptation of national products to international standards of quality and safety. In December 2017 the Government of Ukraine approved the Export Strategy of Ukraine in 2017-2021 defines strategic goals for the development of Ukraine's trade over the next four years, including creating conditions for the development of trade for the diversification of exports of Ukrainian goods and services, support for exports on the part of the state, as well as raising the level of knowledge and skills necessary for enterprises to implement international trade. The prospective sectors of the Ukrainian economy include the food and processing industry. One of the key elements of the implementation of the Concept of International Food Security and the Export Strategy of Ukraine is to ensure a high level of quality of food products. In Ukraine, a certain legal framework has been developed for this purpose, according to which national exporters should adhere to the basic principles and requirements of the basic EU legislation on food safety and state control in sanitary and phytosanitary measures when entering the EU markets. According to the Comprehensive Implementation Strategy, in the section "Trade and Trade-related Issues", the Association Agreement between Ukraine and the European Union established a plan of measures and terms for their implementation in Ukraine. At the same time, in order to comply with the requirements of the legislation on the safety and 
quality of food products at all stages of their production and circulation, market operators are obliged to introduce on-going procedures in their enterprises, based on the principles of the system of HACCP the system of analysis of risks, hazardous factors and control of critical points, which guarantees the production of safe products. In general, the improvement of Ukraine's food security legislation and its approximation to the EU legislation should be an incentive for the development of international trade and the enhancement of Ukraine's participation in international food security. Important elements of approximation of legislation to international standards is the strengthening of trust through good practice in regulating and controlling food quality.

Keywords: food security, export strategy, market operators, state regulation of product safety, HACCP system.

Попко Е. В., к.э.н., доцент (Национальный университет водного хозяйства и природопользования, г. Ровно)

ОТЕЧЕСТВЕННЫЙ ЗАКОНОДАТЕЛЬНЫЙ БАЗИС АДАПТАЦИИ К ЕВРОПЕЙСКОЙ МОДЕЛИ КОНТРОЛЯ КАЧЕСТВА И БЕЗОПАСНОСТИ ПИЩЕВОЙ ПРОДУКЦИИ

Обоснована целесообразность и приоритетные направления внедрения международной системы контроля качества и безопасности пищевой продукции отечественными операторами рынка. Проведен анализ законодательной базы Украины по вопросам качества и безопасности пищевой продукции. Определены преимущества от внедрения в практику отечественных промышленных предприятий базовых принципов системы НАССР.

Ключевые слова: продовольственная безопасность, экспортная стратегия, операторы рынка, государственное регулирование безопасности продукции, система ХАССП. 